\title{
Relaksasi pernafasan dan dzikir menurunkan tingkat kecemasan pada ibu hamil HIV positif: Literature review
}

\author{
Tina Mawardika ${ }^{1 *}$, Imami Nur Rahmawati ${ }^{2}$, Wiwit Kurniawati ${ }^{3}$ \\ ${ }^{1}$ Fakultas Ilmu Keperawatan, Universitas Ngudi Waluyo, Indonesia \\ ${ }^{2,3}$ Fakultas IImu Keperawatan, Universitas Indonesia, Indonesia \\ *Coresponding Author: tinamawardika@gmail.com
}

\begin{abstract}
Abstrak
Pendahuluan: Kehamilan dengan HIV merupakan sumber kebahagiaaan bagi seorang ibu, namun juga menjadi sumber kecemasan yang disebabkan adanya kekhawatiran ibu tentang penularan penyakit pada janin yang dikandungnya. Kondisi kecemasan berlebihan mempengaruhi kondisi kesehatan fisik dan psikis ibu serta janin yang dikandungnya. Penelitian ini bertujuan untuk menurunkan derajat kecemasan ibu hamil dengan HIV positif. Metode: Metode penelitian ini adalah Evidence Based Practice Nursing. Sampel dalam penelitian ini adalah lima ibu hamil dengan HIV positif dan beragama islam. Alat ukur yang digunakan dalam penelitian ini adalah Perinatal Anxiety Screening Scale (PASS) dalam bentuk kuesioner, yang diberikan dua kali kepada subjek yaitu sebelum dan sesudah intervensi relaksasi pernafasan dan dzikir. Hasil: Penelitian menunjukkan terdapat penurunan tingkat kecemasan ibu hamil dengan HIV positif. Simpulan: Relaksasi pernapasan dan dzikir dapat digunakan sebagai salah satu cara untuk menurunkan derajat kecemasan ibu hamil dengan HIV positif.
\end{abstract}

Kata kunci: Dzikir; ibu hamil; HIV; kecemasan; relaksasi pernapasan

\section{Breathing relaxation and dhikr decreased anxiety level of pregnant mother with HIV Positive: Literature review}

\begin{abstract}
Introduction: Several research indicated that pregnancy with HIV is not only the source of pregnant mother happiness, but also source of their anxiety. Whereas, excessive anxiety influence physical and psychological health condition for both the mother and the baby. This study aimed to determine the effect of Breathing Relaxation and Dhikr on level of anxiety of pregnant mother with HIV positive. Methods: The methodology used in this study with Evidence Based Practice Nursing. The sample in this study was five pregnant mother with HIV positive and muslim. The questionnairein this study use Perinatal Anxiety Screeninf Scale (PASS), which is given two times, before and after the intervention. Results: Result of this study showed there is a gain of anxiety level of pregnant mother with HIV positive. Conclusions: This study find out that the breathing relaxation and dhikr can reduce anxiety level of pregnant mother with HIV positif.
\end{abstract}

Keywords: Dhikr; pregnant mother; HIV; anxietyt; breathing relaxation

How to Cite: Mawardika, T., Rahmawati, I.N., Kurnawati, W. (2020). Relaksasi pernafasan dan dzikir menurunkan tingkat kecemasan pada hamil HIV AIDS: Literature review. NURSCOPE: Jurnal Penelitian dan Pemikiran Ilmiah Keperawatan, 6(1), 101-108

\section{PENDAHULUAN}

Pada masa kehamilan, ibu mengalami perubahan yang signifikan pada fungsi fisiologis dan psikologisnya, proses adaptasi terhadap keadaan barunya ini kemudian menimbulkan kecemasan (Misri et al., 2010). Kehamilan adalah periode krisis yang melibatkan faktor psikologis mendalam, yang terjadi karena adanya perubahan somatic yang sangat besar. Perubahan somatic tersebut diantaranya adalah mual dan muntah (morning sicknes) pusing, cepat lelah, rasa sakit pada payudara, dan bertambahnya nafsu makan, sedangkan pada trimester tiga semakin banyak keluhan fisik yang dialami ibu hamil seperti sembelit, varises pada kaki, sakit pinggang, sulit tidur, sulit bernafas dan keinginan untuk buang air kecil yang semakin sering (Fairbrother, Janssen, Antony, 
Tucker, \& Young, 2016). Gejala tersebut muncul pada ibu hamil karena adanya perubahan hormone pada ibu hamil yang juga menyebabkan emosi ibu menjadi labil dan menimbulkan kecemasan. Kecemasan tidak hanya dirasakan pada ibu hamil pada umumnya, kecemasan tersebut akan meningkat pada ibu hamil dengan resiko tinggi. Salah satunya adalah pada ibu hamil dengan HIV Positif. Infeksi HIV pada kehamilan sangat berbahaya bagi ibu dan akan menimbulkan dampak pada janin yang dikandungnya (Anglewiezs \& Reniers, 2014).

Kejadian ibu hamil HIV positif di DKI Jakarta menjadi peringkat pertama di Indonesia, yaitu sebanyak 2.887 kasus, kemudian peringkat kedua Papua sebanyak 2.128."Tingginya HIV positif di provinsi ini karena pengaruh perilaku seks bebas," Kemudian peringkat ketiga adalah Jawa Barat sebanyak 1.690, Jawa Tengah 1.627, Jawa Timur 1.246, Bali 1.000 ibu hamil yang ODHA. Yang membuat miris adalah jumlah anak di bawah usia empat tahun yang terpapar HIV positif dalam lima tahun terakhir yaitu pada 2013 sebanyak 758, kemudian 2014 sebanyak 460, tahun 2015 sebanyak 906 kemudian pada 2016 sebanyak 903. Pada pertengahan tahun 2017 angka yang tercatat saat ini sebanyak 459 (Kemenkes, 2017).

Janin dapat tertular oleh virus yang ada pada tubuh ibu hamil dengan HIV positif. Penularan dapat terjadi mulai dari masa kehamilan (40\%), persalinan maupun masa nifas (65\%) pada saat ibu menyusui yang ditularkan melalui ASI (60\%) (Augusto, 2016). Kondisi tersebut akan meningkatkan kecemasan pada ibu hamil dengan HIV Positif. Jika kecemasan tidak ditangani akan menimbulkan dampak lebih lanjut seperti depresi antepartum yang akan berpengaruh pada status kesehatan ibu dan janin yang dikandungnya.

Kecemasan kehamilan adalah keadaan emosional yang mirip dengan kecemasan pada umumnya namun berbeda karena secara khusus berfokus pada kekhawatiran pada wanita hamil. Didasarkan pada definisi kecemasan secara umum adalah sebagai emosi negatif yang dihasilkan dari persepsi terhadap ancaman kehamilan yang terkait dengan kekhawatiran tentang kesehatan dan kesejahteraan bayi, proses persalinan yang akan datang, pengalaman perawatan kesehatan dirumah sakit, kelahiran dan postpartum, serta peran orang tua atau ibu (Dunkle,2011)

Proses terjadinya kecemasan melibatkan tiga aspek yaitu aspek kognisi (persepsi), reaksi fisiologis (kesiapan melakukan aksi), dan perasaan takut. Ketiganya saling mempengaruhi satu sama lain. Ketika stresor datang, secara kognisi otak mempersepsi stimulus sebagai hal yang tidak menyenangkan (berdasarkan pengalaman sebelumnya). Dalam waktu yang sama, sistem syaraf otonom memerintahkan sistem syaraf simpattis untuk bekerja diantaranya meningkatkan denyut jantung, irama pernafasan, ekskresi keringat, sekresi liur, dan meningkatkan ketegangan (reaksi fisiologis). Amygdala (bagian otak yang mengatur emosi) juga meningkat aktivitasnya. Perubahanperubahan tersebut membuat individu merasa dirinya mengalami ketakutan ataupun kecemasan (Misri et al., 2010).

Para ahli kemudian membagi ciri-ciri kecemasan menjadi dua aspek gejala kecemasan yaitu gejala psikologis dan gejala fisiologis (Fairbrother et al., 2016). Gejala psikologis meliputi gejala yang terkait dengan kondisi emosi dan pikiran seseorang yang mengalami kecemasan seperti takut dan khawatir yang tidak terkendali, merasa tertekan, merasa tidak mudah menghadapi sesuatu yang buruk yang akan terjadi, terus menerus mengeluh tentang perasaan takut terhadap masa depan, percaya sesuatu yang menakutkan akan terjadi dengan sebab yang tidak jelas, kepekaan yang tajam dengan sensasi tubuh, terancam dengan orang atau keadaan yang secara normal tidak diperhatikan, takut kehilangan kontrol, takut tidak bisa menghadapi permasalahan, berpikir hal tertentu berulang-ulang, ingin melarikan diri, bingung, kesulitan berkonsentrasi, perilaku dependen, serta perilaku agitatif (Shiri \& Dennis, 2017). Gejala fisiologis meliputi gejala yang menyangkut kondisi badan atau tubuh seseorang yang cemas, terutama yang menyangkut fungsi sistem syaraf yang ditunjukkan dari 
ekspresinya seperti gemetar, pucat, menggigit kuku, aktivitas kelenjar adrenalin, tidak dapat tidur, perut mual, keringat berlebihan, telapak tangan berkeringat, terasa akan pingsan, perasaan kering di mulut atau tenggorokan, sulit bicara, nafas pendek, jantung berdebar-debar, suara bergetar, tangan dan jari-jari terasa dingin, lemas, sulit menelan, kepala pusing, kekakuan leher atau punggung, sakit perut atau mual,sering buang air kecil, dan diare (Misri et al., 2010)

Secara psikologis kemampuan seseorang dalam menghadapi situasi kecemasan tergantung pada ambang kecemasan yang dimilikinya (Severin, 2007 dalam Tony, 2009). Semakin tinggi ambang kecemasan seseorang, semakin besar daya tahannya untuk merespon cemas yang dialami dengan cara yang terkendali. Sebaliknya, semakin rendah ambang cemas seseorang, maka akan semakin kecil toleransinya terhadap adanya cemas sehingga lebih berpeluang besar untuk kehilangan kendali atas diri dan perilakunya.

Ada beberapa metode yang dapat dilakukan untuk mengurangi kecemasan ibu hamil dengan HIV positif, salah satunya dengan melakukan relaksasi pernafasan dan dzikir. Relaksasi akan membuat individu lebih mampu menghindari reaksi yang berlebihan karena kecemasan. Mengelola dirinya dengan menjaga ketenangan emosi. Ketenangan emosi diperlukan agar seseorang memiliki waktu untuk melihat suatu situasi yang sedang dialami dengan menggunakan sudut pandang yang lebih positif. Ketenangan emosi bisa terwujud dalam keadaan aspek fisiologisnya juga berada dalam keadaan rileks (Sellakumar, 2015).

Penelitian yang terkait diantaranya adalah Muller, Hammill \& Hermann (2016) menemukan bahwa terapi relaksasi otot progresif mampu menurunkan stres dan kecemasan pada ibu maternal. Terdapat perubahan penurunan derajat kecemasan ibu hamil trimester III dengan menggunakan relaksasi dan dzikir (Rohayati, 2017). Pelatihan Relaksasi dengan Dzikir dapat digunakan sebagai salah satu cara untuk menurunkan kecemasan kehamilan ibu hamil pertama (Maimunah dan Retnowati, 2011).

Berdasarkan beberapa hasil penelitian tersebut dapat dinyatakan bahwa berbagai terapi relaksasi cukup efektif untuk menurunkan kecemasan, artinya secara non farmakologis mampu menggantikan terapi farmakologis, yang dikhawatirkan dapat memberikan efek samping tertentu yang tidak baik bagi kesehatan ibu hamil dengan HIV positif. Berkaitan dengan kondisi tersebut, maka perawat spesialis akan melakukan relaksasi Relaksasi pernafasan dan dzikir untuk menurunkan kecemasan pada ibu hamil dengan HIV Positif. Relaksasi pernafasan merupakan latihan pernapasan dengan teknik bernapas secara perlahan dan dalam, menggunakan otot diafragma, sehingga memungkinkan abdomen terangkat perlahan dan dada mengembang penuh (Arlinghaus, Markofski, \& Johnston, 2017).

Relaksasi pernafasan merupakan latihan pernapasan dengan teknik bernapas secara perlahan dan dalam, menggunakan otot diafragma, sehingga memungkinkan abdomen terangkat perlahan dan dada mengembang penuh (Arlinghaus, Markofski, \& Johnston, 2017). Relaksasi pernafasan ini telah terbukti mampu menjadi salah satu metode pengobatan. Penelitian yang dilakukan oleh Rokawie, Sulastri, dan Anita (2017) menemukan bahwa terbukti relaksasi pernafasan mampu menurunkan kecemasan pasien pre operasi bedah. Penelitian yang dilakukan oleh Tarwoto (2012) menemukan bahwa terapi Relaksasi pernafasan terbukti mampu menurunkan nyeri kepala akut pada pasien cedera kepala ringan. Penelitian Sepdianto (2010) menemukan bahwa terapi Relaksasi pernafasan mampu menurunkan tekanan darah dan tingkat kecemasan pasien hipertensi primer di Kota Blitar. Penelitian Sellakumar dan Kannaiah (2015) menemukan bahwa latihan slow deep breathing mampu menurunkan tingkat kecemasan pada siswa remaja. 
Kecemasan ibu hamil dengan HIV Positif juga dapat diminimalisir dengan adanya dzikir. Dzikir secara etimologi berasal dari kata adz-dzikr yang artinya ingat. Dzikir berarti mensucikan dan mengagungkan, menyebut dan mengucapkan nama Allah, menjaga dalam ingatan (mengingat Allah), mengingat nikmat-nikmat Allah, takut dan berharap hanya kepada-Nya, merasa yakin bahwa diri manusia selalu berada di bawah kehendak Allah dalam segala hal dan urusannya (Wulandari \& Huriyati, 2015). Dzikir sebagai salah satu dari psikoreligius yaitu segala aktivitas yang berhubungan dengan ajaran agama berdasarkan peraturan atau perudang-undangan yang terkandung di dalamnya, dimana aktivitas keagamaan yang dilakukan itu mempunyai pengaruh terhadap kondisi mental seseorang termasuk kecemasan ibu postpartum. Penelitian yang dilakukan oleh Maemunah \& Retnowati (2011) menunjukkan bahwa pelatihan relaksasi dengan dzikir secara signifikan dapat mengurangi kecemasan responden dalam menghadapi kehamilan pertama.

Kelebihan penerapan EBNP ini adalah tehnik relaksasi yang dipilih merupakan relaksasi pernapasan yang dinilai lebih aman bagi ibu hamil dengan HIV positif, lebih sederhana dan mudah dipraktekkan. Selain itu, penerapan EBPN yang menggunakan relaksasi dengan dzikir untuk menurunkan kecemasan ibu hamil dengan HIV positif.Penerapan EBPN ini bertujuan untuk mengetahui pengaruh relaksasi pernapasan dan dzikir dalam mengurangi tingkat kecemasan yang dialami oleh ibu hamil dengan HIV positif.

\section{METODE}

Metode penelitian yang dilakukan adalah Evidence Based Practice Nursing. Data yang didapatkan kemudian akan dianalisis dengan menggunakan analisa statistika deskriptif berupa grafik dan tabel. No Hasil Uji Etik No.96/UN2.F12.D/HKP.02.04/2018. Langkah dalam pelaksanaan Evidence Based Practice Nursing melewati beberapa tahapan yaitu: P (Patient, Population \& Problem), I (Inervention), C (Comparison) dan O (Outcome) atau yang dikenal dengan "PICO". Patient, Population \& Problem: Subyek dalam penelitian ini adalah lima orang ibu hamil dengan HIV positif yang berusia 20-37 tahun, dengan usia kehamilan 20 - 32 minggu, memiliki kecemasan yang diukur dengan alat ukur kecemasan khusus (Perinatal Anxiety Screening Scale (PASS), dan lembar observasi) untuk ibu hamil dan beragama islam

Intervention: Pelaksanannya yaitu penilaian PASS diberikan saat pertama kali bertemu dengan pasien. Lalu pasien diberikan penjelasan terkait manfaat relaksasi pernafasan dan dzikir. Kelima pasien mengatakan tertarik dan mengatakan akan mencoba rutin melaksanakannya setiap hari. Pelaksanaan relaksasi pernafasan dan dzikir dilakukan dalam kondisi nyaman dan rileks, pejamkan kedua mata, menarik nafas dalam melalui hidung selama 4 detik/hitungan sampai dada dan abdomen terasa terangkat maksimal, jaga mulut tetap tertutup selama menarik nafas (inspirasi), tahan nafas selama 2 detik/hitungan, menghembuskan nafas melalui bibir yang dirapatkan dan sedikit terbuka dalam 4 detik/hitungan, Istirahat selama 2 detik/hitungan dengan nafas biasa, ulangi sebanyak 5x (nafas dalam 5x selama 1 menit), melakukan dzikir (pertama) selama 2 menit perlahan, nada lembut, dan dirasakan merasuk ke dalam hati dengan bernafas biasa, melakukan relaksasi pernafasan dan dzikir berulang sebanyak 5 siklus selama 15 menit, 2 kali sehari, selama 3 hari. Evaluasi hasil dilakukan saat klien sudah berada di rumah, dengan melakukan kunjungan rumah Comparison: Membandingkan tingkat kecemasan ibu hamil dengan HIV Positif sebelum dan sesudah terapi relaksasi pernafasan dan dzikir

\section{HASIL DAN PEMBAHASAN}

Tabel 1 dan Grafik 1 menunjukkan bahwa subyek 1,2 dan 5 mengalami penurunan tingkat kecemasan yang sangat signifikan, sedangkan subyek 3 dan 4 terdapat penurunan derajat kecemasan yang cukup signifikan setelah mendapatkan terapi relaksasi pernafasan dan dzikir. Penerapan EBPN ini membuktikan bahwa relaksasi pernafasan dan dzikir secara signifikan dapat mengurangi kecemasan subjek dalam menghadapi kehamilan dengan HIV positif. 
Keterangan:

0-20 : Cemas Ringan

21-41 : Cemas Sedang

42-93 : Cemas Berat

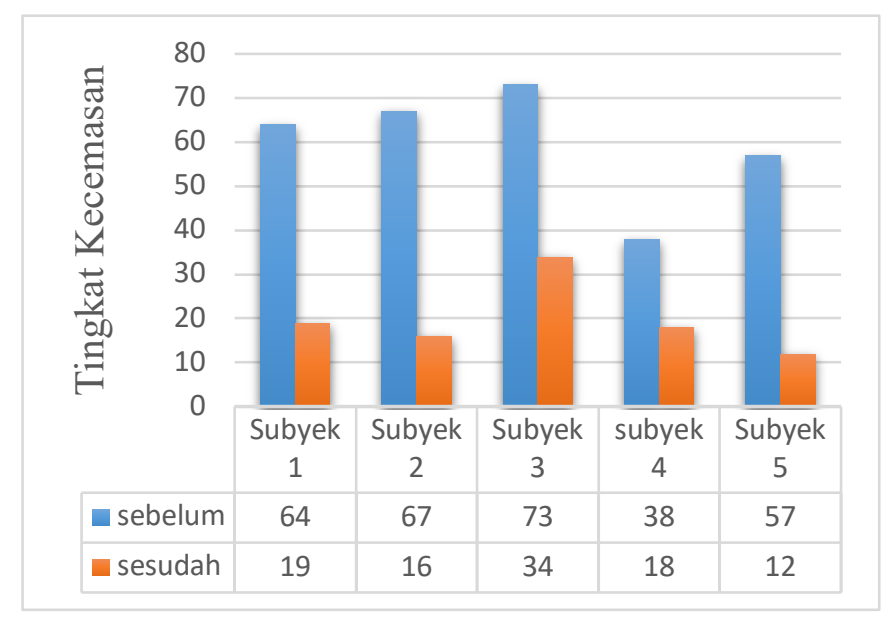

Grafik 1. Tingkat kecemasan ibu hami dengan HIV Positif sebelum dan sesudah terapi relaksasi pernafasan dan dzikir

Tabel 1. Data persentase tingkat kecemasan ibu hamil dengan HIV Positif sebelum dan sesudah terapi relaksasi pernafasan dan dzikir

\begin{tabular}{cccccc}
\hline Subyek & Umur & Pre & Post & Selisih & Persentase (\%) \\
\hline $\mathbf{1}$ & 26 th & 64 & 19 & 45 & $70,31 \%$ \\
$\mathbf{2}$ & 30 th & 67 & 16 & 51 & $76,2 \%$ \\
$\mathbf{3}$ & 30 th & 73 & 34 & 39 & $53,9 \%$ \\
$\mathbf{4}$ & 20 th & 38 & 18 & 20 & $52,63 \%$ \\
$\mathbf{5}$ & 32 th & 57 & 12 & 45 & $78,95 \%$ \\
\hline
\end{tabular}

Keterangan : Nilai Median 70,31\%, jika selisih lebih besar dari 70,31\%, maka terjadi penurunan kecemasan yang sangat signifikan

Hasil penelitian yang signifikan mendukung beberapa penelitian yang sebelumnya yang menyatakan bahwa relaksasi dapat mengatasi kecemasan ibu hamil (Maimunah\& Retnowati, 2011). Penelitian ini dapat membuktikan bahwa relaksasi dengan dzikir juga dapat membantu mengurangi kecemasan kehamilan. Bedanya, penelitian ini melibatkan unsur keyakinan yang dimiliki oleh subjek.

Ibu hamil dengan HIV Positif yang melakukan relaksasi pernafasan dengan dzikir, setelah melaksanakan latihan tersebut ibu hamil dengan HIV Positif merasa lebih tenang, nyaman, lebih dekat dengan Allah dan lebih pasrah menerima berbagai keadaan yang kurang menyenangkan bagi dirinya dalam hal ini adalah kondisi kehamilan dengan HIV Positif. Terapi relaksasi pernafasan dengan dzikir adalah teknik yang mengurangi ketegangan-ketegangan yang melibatkan kelompokkelompok otot tertentu yang dipadukan dengan ajaran agama Islam yaitu dengan melafadzkan dzikir. Melalui praktek berulang, individu dapat belajar untuk mengenali dan membedakan perasaan yang terkait dari otot tegang dan otot santai. Menegangkan dan melepaskan berbagai kelompok otot di seluruh tubuh dapat menghasilkan keadaan rileks (Sellakumar, 2015).

Relaksasi dengan dzikir adalah sebuah metode yang digunakan dengan harapan dapat mengurangi kecemasan kehamilan. Terapi ini merupakan pengembangan dari respon relaksasi yang dikembangkan oleh Maimunah \& Retnowati (2011), dimana relaksasi ini merupakan gabungan dari antara relaksasi dengan keyakinan agama yang dianut. Relaksasi pernafasan dengan dzikir melatih individu untuk mengendurkan otot-otot dan menghayati perbedaan situasi tegang dan rileks, setelah 
pengendoran otot dicapai, tahapan selanjutnya adalah memasukkan unsur keyakinan atau religius sambil melakukan relaksasi pernafasan yang membantu mengurangi kecemasan dengan cara mengatur langkah dan kedalaman pernafasan (Indonesia, Pasca, Fakultas, Keperawatan, \& Indonesia, 2008) .

Maimunah dan Retnowati (2011) menyatakan bahwa konsep relaksasi yang menerapkan ajaran agama ini bertujuan untuk mendapatkan kondisi rileks yang berlipat, karena selain otot (fisik) yang dilemaskan, penggunaan unsure agama dapat memudahkan ibu hamil dengan HIV Positif untuk memusatkan perhatian dan membantu menenangkan pikiran juga sikap pasrah dan berserah kepada Tuhan menambah kondisi rileks dan keadaan jiwanya menjadi lebih tenang.

Terdapat dua karakteristik individu yang berpengaruh dalam proses penilaian kognitif, yaitu commitment dan belief. Dengan melibatkan dzikir pada terapi relaksasi ini, meningkatkan belief subyek, terutama existensial belief subyek. Pada proses pembentukan kecemasan, Relaksasi pernafasan dengan dzikir yang dilakukan oleh subyek dapat membentuk proses cognitive reappraisal follows, yaitu proses dimana individu kemudian menilai kembali situasi yang mengancam tersebut, sehingga individu tersebut dapat menggunakan koping yang lebih baik daripada sebelumnya yang menimbulkan reaksi kecemaan (Yamada, Inoue, Mafune, Hiro, \& Nagata, 2017).

Ibu hamil dengan HIV positif yang pada awalnya merasakan kecemasan mengenai kehamilannya dikarenakan memandang kehamilan dengan HIV positif sebagai sesuatu yang mengancam janinnya dan memberi dampak negative kepada kehidupannya, seperti subyek 3 yang mengatakan bahwa kehamilannya ini membuat dia ketakutan jika anak yang dikandungnya akan tertular virus HIV seperti kakaknya, belum lagi kondisi keuangan yang belum memadai saat ini, apabila nanti anak sudah lahir, akan bertambah lagi pengeluaran yang harus ditanggung. Setelah diberikan relaksasi pernafasan dengan dzikir, semua ibu hamil dengan HIV positif mengaku tidak lagi memandang kehamilan dengan HIV positif yang dijalaninya sebagai suatu hal yang memberikan dampak negative pada janin yang dikandungnya. Dengan kata lain, relaksasi pernafasan dengan dzikir mempengaruhi cognitive appraisal subyek dalam tataran existensial belief'nya. Relaksasi dengan dzikir menguatkan existensial belief ibu hamil dan memunculkan suatu keyakinan bahwa kehamilan sebagai suatu takdir yang harus dijalani, atau yang menganggap kehamilan sebagai suatu anugerah dari Tuhan, sehingga ibu hamil dengan HIV positif lebih bisa menjalani kehamilannya dengan lebih tenang, memasrahkan semua kekhawatiran yang ada sebelumnya, apapun yang akan terjadi semua adalah kehendak Allah SWT (Maimunah \& Retnowati, 2011).

Keterbatasan

Penerapan Evidence Based Practice Nursing (EBPN) ini dilakukan pada jumlah subjek yang sangat kecil (hanya lima orang) karena proses yang tidak mungkin berjalan dengan efektif jika dilakukan dengan jumlah subjek yang lebih banyak. Selain itu hal ini juga dilakukan karena adanya kesulitan pencarian ibu hamil dengan HIV positif yang sesuai kriteria inklusi. Desain dengan subjek yang sedikit memungkinkan melihat dinamika yang terjadi pada masing-masing subjek. Namun demikian, hasil penerapan EBPN ini belum dapat digeneralisasikan secara luas karena subjeknya yang belum mewakili populasi. Hasil penerapan EBPN ini hanya menjelaskan keadaan kelompok subjek saja.

Implikasi keperawatan

Penerapan asuhan keperawatan pada ibu hamil dengan HIV positif harus lebih komprehensif dan sesuai dengan kebutuhan dan intervensi yang tepat sasaran guna meningkatkan status kesehatannya. Peran perawat sebagai peneliti yaitu menggunakan riset untuk meningkatkan mutu pelayanan dan asuhan keperawatan pada ibu hamil dengan resiko tinggi (HIV positif )meliputi memberikan terapi non farmakologi dalam mengurangi kecemasan dengan relaksasi pernapasan dan dzikir dengan tujuan dapat meningkatkan status kesehatannya ibu dan janinya 


\section{SIMPULAN DAN SARAN}

Berdasarkan penerapan Evidence Based Practice Nursing (EBPN) didapat hasil bahwa pemberian terapi relaksasi pernafasan dan dzikir secara signifikan dapat menurunkan tingkat kecemasan ibu hamil dengan HIV Positif. Penurunan tingkat kecemasan pada setiap subjek terlihat dari selisih penurunan skor sebelum dan sesudah melakukan treatment relaksasi pernafasan dan dzikir.

Pemberian terapi relaksasi pernafasan dan dzikir dapat menjadi salah satu alternative terapi yang dapat digunakan kepada ibu hamil dengan HIV positif yang mengalami kecemasan dengan menurunkan tingkat kecemasan yang dialaminya. Terapi relaksasi pernafasan dan dzikir dapat digunakan untuk menurunkan tingkat kecemasan dengan mencapai keadaan yang lebih rileks dan menenangkan bagi ibu hamil dengan HIV Positif yang mengalami kecemasan. Dengan mencapai keadaan rileks dan menenangkan tersebut, ibu hamil menjadi lebih optimis dan berpikir positif terhadap kehamilan yang sedang dijalani dan segala hal yang akan terjadi di masa mendatang, ibu hamil memiliki sikap pasrah dan menyerahkan segala sesuatunya kepada Allah SWT. Subjek penelitian diharapkan tetap menerapkan relaksasi dengan dzikir di rumah agar manfaat yang dirasakan tetap akan dirasakan atau bahkan diharapkan bertambah jika semakin sering dilatihkan.

\section{DAFTAR PUSTAKA}

Arlinghaus, K. R., Markofski, M. M., \& Johnston, C. A. (2017). Reducing Anxiety to Increase Exercise in Individuals With Decreased Lung Capacity. American Journal of Lifestyle Medicine, 11(4), 307309. http://doi.org/10.1177/1559827617703058

Augusto, G. F. (2016). Use of services for prevention of mother-to-child transmission of HIV in Angola: a retrospective analysis. The Lancet Global Health, 382, 13. http://doi.org/10.1016/S0140-6736(13)62174-1

Dunkle, K.L., Stephenson, R., Karita, E., Chomba, E., Kayitenkore, K., Vwalika, C., \& Allen, S. (2008). New heterosexually transmitted HIV infections in married or cohabiting couples in urban Zambia and Rwanda: an analysis of survey and clinical data. The Lancet, 371(9631), 2183-2191.

Fairbrother, N., Janssen, P., Antony, M. M., Tucker, E., \& Young, A. H. (2016). Perinatal anxiety disorder prevalence and incidence. Journal of Affective Disorders, 200, 148-155. http://doi.org/10.1016/j.jad.2015.12.082

Indonesia, U., Pasca, P., Fakultas, S., Keperawatan, I., \& Indonesia, U. (2008). Pengaruh latihan slow Relaksasi pernafasan terhadap tekanan darah dan tingkat kecemasan pasien hipertensi primer di kota blitar.

Kasi, P. M., Naqvi, H. A., Afghan, A. K., Khawar, T., Khan, F. H., Khan, U. Z., ... Khan, H. M. (2012). Coping Styles in Patients with Anxiety and Depression. ISRN Psychiatry, 2012, 128672. http://doi.org/10.5402/2012/128672

Kemenes RI, (2017).Prevalensi Kejadian HIV di Indonesia. Kementrian Kesehatan republic Indonesia. Direktorat Jendral Pengendalian Penyakit dan Kesehatan Lingkungan.

Maimunah, A. (2011). Kajian Utama Pengaruh Pelatihan Relaksasi Dengan Dzikir Untuk Mengatasi Kecemasan Ibu Hamil Pertama, 8(1), 1-22.

Maimunah, A., \& Retnowati, S. (2011). Pengaruh Pelatihan Relaksasi dengan Dzikir Untuk Mengatasi Kecemasan Ibu Hamil Pertama. Jurnal Psikologi Islam, 8(1), 1-22. Retrieved from 
http://etd.repository.ugm.ac.id/index.php?mod=penelitian_detail\&sub=PenelitianDetail\&act= view\&typ=html\&buku_id=51251\&obyek_id=4.

Misri, S., Kendrick, K., Oberlander, T. F., Norris, S., Tomfohr, L., Zhang, H., \& Grunau, R. E. (2010). Antenatal Depression and Anxiety Affect Postpartum, 55(4).

Muller, A., Hammill, H. V., \& Herman, C. (2016). The Effects of Pilates and Progressive Muscle Relaxation Therapy on Maternal Stress and Anxiety: a Literature Review. International Journal of Humanities and Social Science, 6(6), 2220-8488.

Priyanto. (2010). Pengaruh Relaksasi pernafasan Exercise Terhadap Fungsi Ventilasi Oksigenasi Paru Pada Klien Post Ventilasi Mekanik. Tesis. Depok: Universitas Indonesia. (Tidak Dipublikasikan).

Rohayati, N. (2017). Pengaruh Relaksasi dan Dzikir dalam menurunkan kecemasan pada ibu hamil trimester III, iii, 1-11.

Sellakumar, G. K. (2015). Effect Of Slow-Relaksasi Pernafasan Exercise To Reduce Anxiety Among Adolescent School Students In A Selected Higher Secondary, 23(1), 54-72.

Shiri, R., \& Dennis, C. (2017). The prevalence of antenatal and postnatal co-morbid anxiety and depression : a meta-analysis, 2041-2053. http://doi.org/10.1017/S0033291717000617

Tony, Irwan. (2009). Pengaruh terapi relaksani islami terhadap penurunan kecemasan dan depresi: Studi kasus pada penderita yang mengalami hemodialisa. Tesis. Tidak diterbitkan. Bandung: Universitas Islam Bandung.

Wulandari, I., \& Huriyati, A. (2015). Anxiety's Level of Bantenes Patient's: The Effect of Dhikr Therapy Before Surgical Procedure. International Journal of Research in Medical Sciences, 3(0), S36S40. http://doi.org/10.18203/2320-6012.ijrms20151518

Yamada, T., Inoue, A., Mafune, K., Hiro, H., \& Nagata, S. (2017). Recovery of Percent Vital Capacity by Breathing Training in Patients With Panic Disorder and Impaired Diaphragmatic Breathing. http://doi.org/10.1177/0145445517711436 